\title{
Characterization and catalytic oxidation of carbon monoxide over supported cobalt catalysts
}

\author{
Chen-Bin Wang ${ }^{\mathrm{a}, *}$, Chih-Wei Tang ${ }^{\mathrm{a}, \mathrm{b}}$, Hsin-Chi Tsai ${ }^{\mathrm{a}, \mathrm{b}}$ and Shu-Hua Chien ${ }^{\mathrm{b}, \mathrm{c}, *}$ \\ ${ }^{a}$ Department of Applied Chemistry, Chung Cheng Institute of Technology, National Defense University, Tahsi, Taoyuan, 33509 Taiwan, \\ Republic of China \\ ${ }^{\mathrm{b}}$ Institute of Chemistry, Academia Sinica, Taipei, Taiwan 11529, Republic of China \\ ${ }^{\mathrm{c}}$ Department of Chemistry, National Taiwan University, Taipei, Taiwan 10764, Republic of China
}

Received 1 December 2005; accepted 15 December 2005

\begin{abstract}
Three types of supported cobalt catalysts $\left(\mathrm{CoO}_{x} / \mathrm{SiO}_{2}, \mathrm{CoO}_{x} / \mathrm{TiO}_{2}\right.$ and $\left.\mathrm{CoO}_{x} / \mathrm{Al}_{2} \mathrm{O}_{3}\right)$ were prepared by incipient wetness impregnation with aqueous $\mathrm{Co}\left(\mathrm{NO}_{3}\right)_{2} \cdot 6 \mathrm{H}_{2} \mathrm{O}$ solution. The phase composition and the interactions of cobalt with supports under different calcined temperatures were investigated using thermogravimetry (TG), $\mathrm{N}_{2}$-adsorption at $-196{ }^{\circ} \mathrm{C}, \mathrm{X}$-ray diffraction (XRD), temperature-programmed reduction (TPR) and diffuse reflectance spectroscopy (DRS). Their catalytic activities towards the $\mathrm{CO}$ oxidation were further studied in a continuous flow micro-reactor. The results showed that the interaction of cobalt oxide with supports was much stronger in the kinds of $\mathrm{Al}_{2} \mathrm{O}_{3}$ and $\mathrm{TiO}_{2}$, while no conclusive evidence of any interaction was found for $\mathrm{SiO}_{2}$. Besides the crystalline $\mathrm{Co}_{3} \mathrm{O}_{4}$ which was formed in three supported catalysts, both high-temperature phases $\mathrm{CoAl}_{2} \mathrm{O}_{4}$ and $\mathrm{CoTiO}_{3}$ spinel were also detected under XRD, DRS and TPR analysis. The degree of interaction between cobalt oxide and the support not only affected the surface area and reduction behavior of the catalysts, the catalytic activity toward the CO oxidation also affected simultaneously. As the $\mathrm{CoAl}_{2} \mathrm{O}_{4}$ and $\mathrm{CoTiO}_{3}$ spinel formed, both the surface area and catalytic activity decreased significantly.
\end{abstract}

KEY WORDS: cobalt oxide; supported cobalt catalysts; surface area.

\section{Introduction}

The catalytic oxidation of carbon monoxide is one of the most important reactions in environmental protection. Both platinum group metals and transition metal oxides have been found to catalyze the oxidation. The high cost of previous metals and their sensitivity to sulfur poisoning have motivated the search for substitute catalysts. In recent years, the research on $\mathrm{CO}$ oxidation is flourishing in the use of catalysts which contain bulk and supported metal oxides [1-8]. Metal oxides are widely used in the field of heterogeneous catalysis, both as catalysts and as supports. In such applications the performance is determined by some parameters like bulk metal oxide, surface area and the surface oxide structure. Accordingly, metal oxides must have high stabilities as well as high surface areas under conditions of their use both as catalysts and as support materials [9]. Among the transition metal oxides, cobalt oxide is one of the versatile materials that is of interest to this study.

The types of cobalt oxide and surface area can affect the activity of $\mathrm{CO}$ oxidation. Our previous studies [8] indicated that the relative activity decreased significantly with the oxidation state of cobalt and increased with the

\footnotetext{
* To whom correspondence should be addressed.

E-mails: chiensh@gate.sinica.edu.tw; chenbin@ccit.edu.tw
}

surface area of cobalt oxide. Besides cobalt, the supports for such catalysts, e.g. $\mathrm{Al}_{2} \mathrm{O}_{3}, \mathrm{SiO}_{2}$ and $\mathrm{TiO}_{2}$, are indispensable. Loading a catalyst on an inert but high surface area support improves the accessibility of the active phase. Therefore efforts are plunged to detail studies the structural and chemical properties of these supported cobalt catalysts. During the course of our work, the emphasis is placed on the heat treatment of supported catalysts to express the relationship of the metal-support interactions and the activity of $\mathrm{CO}$ oxidation.

Based on the above, we modified supported catalysts by calcinations under different temperatures and studied the characterization of these catalysts by TG, BET measurements at liquid nitrogen temperature, XRD, DRS and TPR. Their catalytic activities towards the CO oxidation were further studied in a continuous flow micro-reactor.

\section{Experimental}

\subsection{Sample preparation}

Supported cobalt catalysts ( $5 \%$ as metal Co) were prepared by incipient wetness impregnating the supports $\left(\mathrm{Al}_{2} \mathrm{O}_{3}\right.$ (Merck, $150 \mathrm{~m}^{2} \mathrm{~g}^{-1}$ ), $\mathrm{SiO}_{2}$ (Aerosil, $200 \mathrm{~m}^{2} \mathrm{~g}^{-1}$ ) and $\mathrm{TiO}_{2}$ (Degussa $\left.\mathrm{P} 25,55 \mathrm{~m}^{2} \mathrm{~g}^{-1}\right)$ ) with cobalt nitrate solutions. Then, samples were dried at $110^{\circ} \mathrm{C}$ and 
calcined in air (represented as $T_{\mathrm{C}}$ ) at 400,550 and $700{ }^{\circ} \mathrm{C}$, respectively, for $4 \mathrm{~h}$, hereafter named $5 \mathrm{Co} / \mathrm{Al}$ $\mathrm{C} 400,5 \mathrm{Co} / \mathrm{Al} \mathrm{C} 550,5 \mathrm{Co} / \mathrm{Al} \mathrm{C} 700$ (for $\mathrm{CoO}_{x} / \mathrm{Al}_{2} \mathrm{O}_{3}$ catalysts), $5 \mathrm{Co} / \mathrm{Si} \mathrm{C} 400,5 \mathrm{Co} / \mathrm{Si} \mathrm{C} 550,5 \mathrm{Co} / \mathrm{Si} \mathrm{C} 700$ (for $\mathrm{CoO}_{x} / \mathrm{SiO}_{2}$ catalysts), $5 \mathrm{Co} / \mathrm{Ti} \mathrm{C} 400,5 \mathrm{Co} / \mathrm{Ti} \mathrm{C} 550,5 \mathrm{Co} /$ Ti C700 (for $\mathrm{CoO}_{x} / \mathrm{TiO}_{2}$ catalysts), respectively.

\subsection{Techniques of characterization}

Thermal gravimetric analysis (TG/DTG) was carried out using a Seiko TG/DTA 300 system. The rate of heating was maintained at $10{ }^{\circ} \mathrm{C} \mathrm{min}{ }^{-1}$ and the mass of the sample was $\sim 10 \mathrm{mg}$. The measurement was carried from RT to $800{ }^{\circ} \mathrm{C}$ under nitrogen flowing with a rate of $100 \mathrm{ml} \mathrm{min}^{-1}$.

Nitrogen adsorption isotherms at $-196{ }^{\circ} \mathrm{C}$ were determined volumetrically with Micrometritics ASAP 2010. The catalysts were pre-outgassed at $5 \times 10^{-5}$ Torr for $3 \mathrm{~h}$ at $110{ }^{\circ} \mathrm{C}$. The surface area was determined from the nitrogen adsorption isotherm.

The XRD analyses of the samples were carried out using a Siemens D5000 diffractometer. The patterns were run with a Ni-filtered $\mathrm{CuK}_{\alpha 1}$ radiation $(40 \mathrm{kV}$, $30 \mathrm{~mA}, \lambda=1.5405 \AA$ ).

The DRS spectra were measured at room temperature on a Hitachi U3410 spectrophotometer equipped with an integration sphere. The spectra were recorded against a $\mathrm{BaSO}_{4}$ standard in the region 200-2000 nm.

A TPR of supported cobalt catalysts was performed using $10 \% \mathrm{H}_{2}$ in $\mathrm{Ar}$ as a reducing gas. The gas flow rate was adjusted by a mass flow controller under $25 \mathrm{ml} \mathrm{min}{ }^{-1}$. The cell used for TPR was a quartz tube with an $8 \mathrm{~mm}$ inner diameter and the $80 \mathrm{mg}$ catalyst was mounted on a quartz-wool. The hydrogen consumption in the experiment was monitored by a thermal conductivity detector (TCD) raising the sample temperature from RT to $800{ }^{\circ} \mathrm{C}$ at a constant rate of $10{ }^{\circ} \mathrm{C} \mathrm{min}{ }^{-1}$.

\subsection{Activity test}

The catalytic activity of prepared samples towards $\mathrm{CO}$ oxidation was carried out in a continuous flow micro-reactor. A $25 \mathrm{ml} \mathrm{min}{ }^{-1}$ stream of reactant gas (mixed $10 \% \mathrm{O}_{2} / \mathrm{He}$ with $4 \% \mathrm{CO} / \mathrm{He}$ ) was catalyzed with $40 \mathrm{mg}$ of freshly prepared catalysts. The reactor temperature was raised stepwise from a room temperature to $300{ }^{\circ} \mathrm{C}$. The reaction products were analyzed on-line using a Varian 3700 gas chromatograph with a carbosphere column. Before reaction, the catalyst was activated in flowing $10 \% \mathrm{O}_{2} / \mathrm{He}$ at $300{ }^{\circ} \mathrm{C}$ for $3 \mathrm{~h}$.

\section{Results and discussion}

\subsection{Characterization of the supported cobalt catalysts}

Understanding the interaction of cobalt nitrate with supports, TG/DTG is first used to investigate the thermal characterization of supported cobalt catalysts.
Figure 1 shows three DTG curves of as-synthesized catalysts in a dynamic nitrogen $\left(100 \mathrm{ml} \mathrm{min}^{-1}\right)$ environment. There are three distinct mass-loss regions on increasing temperature which are also established. Both $\mathrm{CoO}_{x} / \mathrm{Al}_{2} \mathrm{O}_{3}$ and $\mathrm{CoO}_{x} / \mathrm{SiO}_{2}$ catalysts show similar mass-loss regions (two kinds) except for $\mathrm{CoO}_{x} /$ $\mathrm{TiO}_{2}$ (three kinds). The first region $\left(T \sim 100{ }^{\circ} \mathrm{C}\right)$ is due to the departure of physisorbed water from the supports surface. The second region $\left(T: 100-400{ }^{\circ} \mathrm{C}\right)$ is considered to the decomposition of a nitrate ion. In comparison with the DTG curves, the nitrate ion on both $\mathrm{CoO}_{x} / \mathrm{Al}_{2} \mathrm{O}_{3}$ (figure 1b) and $\mathrm{CoO}_{x} / \mathrm{TiO}_{2}$ (figure 1c) catalysts are slowly decomposed. While, the decomposition of a nitrate ion is fast and continuous on $\mathrm{CoO}_{x} / \mathrm{SiO}_{2}$ (figure 1a), it can be deduced tentatively that the cobalt nitrate is more strongly interacted on both $\mathrm{CoO}_{x} / \mathrm{Al}_{2} \mathrm{O}_{3}$ and $\mathrm{CoO}_{x} / \mathrm{TiO}_{2}$ catalysts. A smaller mass-loss region $\left(T \sim 665^{\circ} \mathrm{C}\right)$ is observed only on $\mathrm{CoO}_{x} / \mathrm{TiO}_{2}$ catalyst when compares with the bulk $\mathrm{Co}_{3} \mathrm{O}_{4}$ [8], this may be due to the decomposition of $\mathrm{Co}_{3} \mathrm{O}_{4}$ to $\mathrm{CoO}$ as following:

$$
2 \mathrm{Co}_{3} \mathrm{O}_{4} \rightarrow 6 \mathrm{CoO}+\mathrm{O}_{2}
$$

In order to further identify the cobalt species in these catalysts, the XRD, DRS and TPR of the as-synthesized and calcined samples are examined. Figures 2-4 show the XRD patterns of supported cobalt catalysts before and after calcinations. Although the peaks of $\mathrm{Co}_{3} \mathrm{O}_{4}$ overlap with those of anatase and rutile, the faint peak of (311) diffraction pattern can be observed on the as-synthesized $\mathrm{CoO}_{x} /$ $\mathrm{TiO}_{2}$ catalyst (figure 4b) which is consistent with the diffraction peaks of cobaltic oxide with a spinel structure $\left(\mathrm{Co}_{3} \mathrm{O}_{4}\right)$. The $\mathrm{Co}_{3} \mathrm{O}_{4}$ crystallite can deposit on titania support before calcinations. From the XRD patterns, it is clear that only $\mathrm{Co}_{3} \mathrm{O}_{4}$ species exist in all calcined temperatures on $\mathrm{CoO}_{x} / \mathrm{SiO}_{2}$ catalyst (figure 2). Since the silica is amorphous, the (311) diffraction pattern of $\mathrm{Co}_{3} \mathrm{O}_{4}$ crystallite is apparent whereby the particle size can be calculated according to the Scherrer equation. The order of $5 \mathrm{Co} / \mathrm{Si} \mathrm{C} 400,5 \mathrm{Co} / \mathrm{Si}$ $\mathrm{C} 550$ and $5 \mathrm{Co} / \mathrm{Si} \mathrm{C700} \mathrm{(figure} \mathrm{2c-e)} \mathrm{is:} \mathrm{11.7,} 12.6$ and $14.1 \mathrm{~nm}$, respectively. In contrast to $\mathrm{CoO}_{x} / \mathrm{SiO}_{2}$, in the XRD patterns of $\mathrm{CoO}_{x} / \mathrm{Al}_{2} \mathrm{O}_{3}$ and $\mathrm{CoO}_{x} / \mathrm{TiO}_{2}$ catalysts cannot distinguish the signals originating from $\mathrm{Co}_{3} \mathrm{O}_{4}$ or other cobalt species. An explanation could be that $\mathrm{Co}_{3} \mathrm{O}_{4}$ signal is hidden behind the $\mathrm{Al}_{2} \mathrm{O}_{3}$ and $\mathrm{TiO}_{2}$ signals. Only the $\mathrm{Co}_{3} \mathrm{O}_{4}$ species undergoes changes in its composition as the calcined temperature above $700{ }^{\circ} \mathrm{C}$ on both $\mathrm{CoO}_{x} /$ $\mathrm{Al}_{2} \mathrm{O}_{3}$ and $\mathrm{CoO}_{x} / \mathrm{TiO}_{2}$ catalysts. The $5 \mathrm{Co} / \mathrm{Al} \mathrm{C} 700$ sample (figure $3 \mathrm{e}$ ) converts into cobalt aluminate spinel $\left(\mathrm{CoAl}_{2} \mathrm{O}_{4}\right)$ with a blue color and $5 \mathrm{Co} / \mathrm{Ti} \mathrm{C} 700$ sample (figure $4 \mathrm{e})$ converts into cobalt titanate spinel $\left(\mathrm{CoTiO}_{3}\right)$ with a green color. 

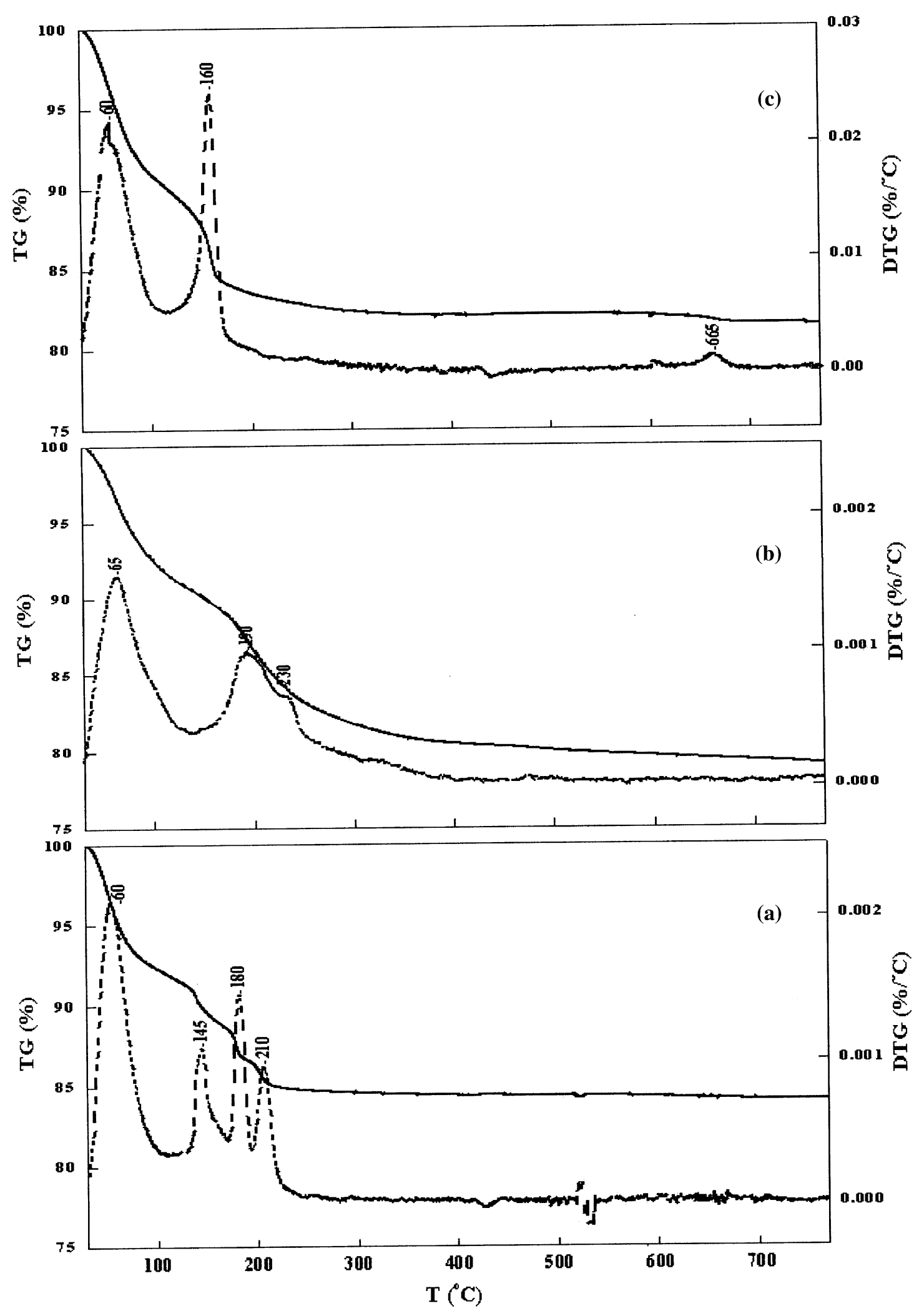

Figure 1. The TG/DTG profiles of supported cobalt catalysts in a dynamic nitrogen environment (a) $\mathrm{CoO}_{x} / \mathrm{SiO}_{2},(\mathrm{~b}) \mathrm{CoO}_{\mathrm{x}} / \mathrm{Al}_{2} \mathrm{O}_{3},(\mathrm{c}) \mathrm{CoO}_{x} / \mathrm{TiO}_{2}$.

The colors of the $\mathrm{CoO}_{x} / \mathrm{Al}_{2} \mathrm{O}_{3}$ and $\mathrm{CoO}_{x} / \mathrm{TiO}_{2}$ catalysts after calcinations at $700{ }^{\circ} \mathrm{C}$ for $4 \mathrm{~h}$ in air turn into other species with blue and green, respectively, from black $\mathrm{Co}_{3} \mathrm{O}_{4}$ species. This is further confirmed by the
DRS spectroscopy. The DRS spectra of $5 \mathrm{Co} / \mathrm{Al} \mathrm{C400,}$ $5 \mathrm{Co} / \mathrm{Al} \mathrm{C} 550$ and $5 \mathrm{Co} / \mathrm{Al} \mathrm{C} 700$ samples are shown in figure 5, while the spectra of $5 \mathrm{Co} / \mathrm{Ti} \mathrm{C} 400,5 \mathrm{Co} / \mathrm{Ti} \mathrm{C} 550$ and $5 \mathrm{Co} / \mathrm{Ti} \mathrm{C} 700$ samples are given in figure 6 . The 
DRS of $5 \mathrm{Co} / \mathrm{Al}(\mathrm{C} 400$ and $\mathrm{C} 550)$ and $5 \mathrm{Co} / \mathrm{Ti}(\mathrm{C} 400$ and $\mathrm{C} 550$ ) (see figures $5 \mathrm{a}, \mathrm{b}$ and $6 \mathrm{a}, \mathrm{b}$ ) display two characteristic bands at 720, $430 \mathrm{~nm}$ and $750,505 \mathrm{~nm}$, respectively, indicating that the formation of $\mathrm{Co}_{3} \mathrm{O}_{4}[10,11]$ is dominant at these temperatures. However, both the $5 \mathrm{Co} / \mathrm{Al} \mathrm{C} 700$ and $5 \mathrm{Co} / \mathrm{Ti} \mathrm{C} 700$ samples (figure $5 \mathrm{c}$ and 6c) show a distinguishing spectrum, which is dominated by characteristic triplet bands at $625,580,545 \mathrm{~nm}$ and $635,600,550 \mathrm{~nm}$, respectively. According to these bands, the $\mathrm{Co}^{2+}$ in both samples should be tetrahedrally coordinated $[10,12,13]$. Such bands obviously correspond to a ${ }^{4} \mathrm{~A}_{2}(\mathrm{~F}) \rightarrow \mathrm{T}_{1}(\mathrm{P})$ transition of $\mathrm{Co}^{2+}$ ions in the tetrahedrally coordinated, as a surface $\mathrm{CoAl}_{2} \mathrm{O}_{4}$ and $\mathrm{CoTiO}_{3}$ spinels. Therefore, we conclude that after the calcinations above $700{ }^{\circ} \mathrm{C}$, the $\mathrm{Co}^{2+}$ ions can diffuse into the $\mathrm{Al}_{2} \mathrm{O}_{3}$ and $\mathrm{TiO}_{2}$ lattice to form cobalt aluminate and cobalt titanate. These results are in good agreement with XRD results.

The BET surface area of the supports and the supported cobalt catalysts are given in table 1 . The data show a gradual decrease in the surface area with an increase of the calcination temperature for the same support catalyst. Such behavior could be attributed to the increase in the crystalline of the formed $\mathrm{CO}_{3} \mathrm{O}_{4}$ or other spinels formed when raising the calcination

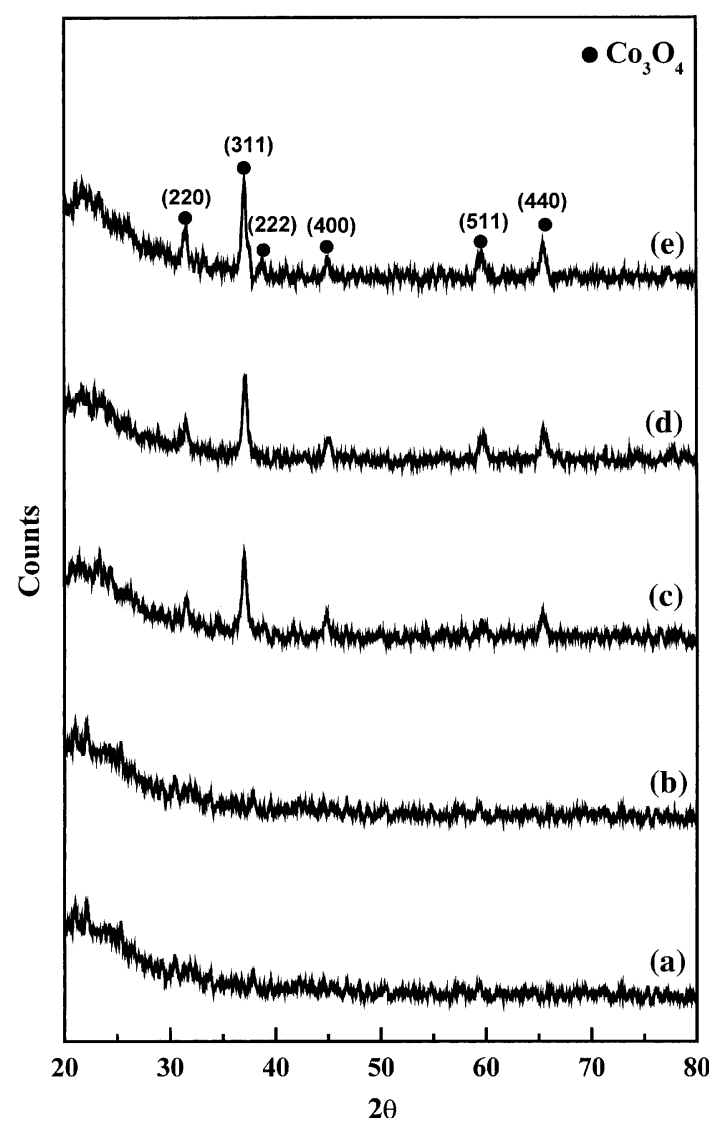

Figure 2. The XRD spectra of $\mathrm{CoO}_{x} / \mathrm{SiO}_{2}$ catalyst (a) $\mathrm{SiO}_{2}$, (b) assyn, (c) $T_{\mathrm{C}}=400{ }^{\circ} \mathrm{C}$, (d) $T_{\mathrm{C}}=550{ }^{\circ} \mathrm{C}$, (e) $T_{\mathrm{C}}=700{ }^{\circ} \mathrm{C}$. temperature. Especially for the spinels, the surface area decreased abruptly from 100 to $78 \mathrm{~m}^{2} \mathrm{~g}^{-1}$ for $\mathrm{CoAl}_{2} \mathrm{O}_{4}$ and from 40 to $1.5 \mathrm{~m}^{2} \mathrm{~g}^{-1}$ for $\mathrm{CoTiO}_{3}$, respectively.

The reducibility of the cobalt species after the calcinations process on supported cobalt catalysts are studied by TPR. Figures 7-9 show the TPR profiles of the following catalysts: $\mathrm{CoO}_{x} / \mathrm{SiO}_{2}, \mathrm{CoO}_{x} / \mathrm{Al}_{2} \mathrm{O}_{3}$ and $\mathrm{CoO}_{x} /$ $\mathrm{TiO}_{2}$. In TPR measurements of $\mathrm{CoO}_{x} / \mathrm{SiO}_{2}$ (figure 7) catalysts, two reduction regions have been observed at around $200{ }^{\circ} \mathrm{C}$ (figure $7 \mathrm{a}$ and $\mathrm{b}$ ) and $300-450{ }^{\circ} \mathrm{C}$ (figure $7 \mathrm{c}-\mathrm{e})$. These reduction regions are assigned to the residue of a nitrate (from cobalt precursor) ion and a $\mathrm{CO}_{3} \mathrm{O}_{4}$ crystallite. Apparently the nitrate ion can be removed completely by calcinations at ca. $400{ }^{\circ} \mathrm{C}$ (figure 7c) [14]. Reduction profiles of the $\mathrm{CoO}_{x} / \mathrm{SiO}_{2}$ catalyst shows two reduction peaks as the calcined temperature above $400{ }^{\circ} \mathrm{C}$, which are similar to those observed in bulk $\mathrm{Co}_{3} \mathrm{O}_{4}[8,15-18]$. These profiles point to a two-step reduction process: the first one is of low intensity at $350^{\circ} \mathrm{C}$ and overlaps with the more intense second one whose maximum is placed at $370{ }^{\circ} \mathrm{C}$ according to the following equations:

$$
\mathrm{Co}_{3} \mathrm{O}_{4}+\mathrm{H}_{2} \rightarrow 3 \mathrm{CoO}+\mathrm{H}_{2} \mathrm{O}
$$

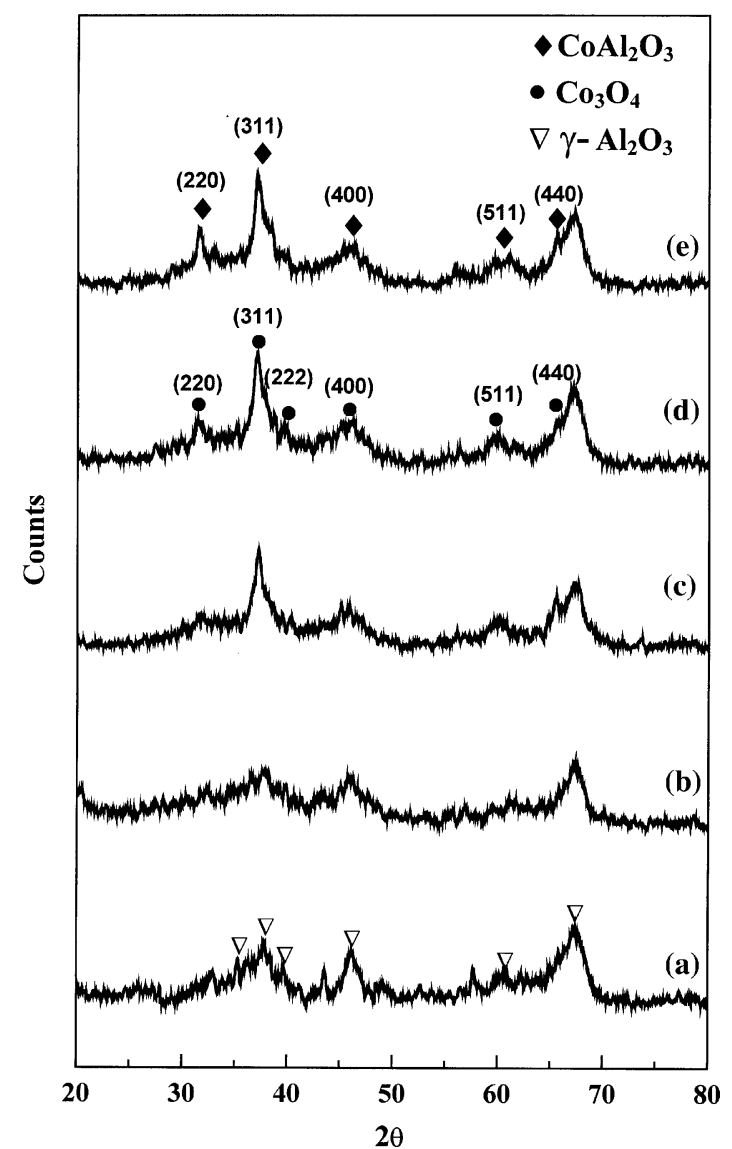

Figure 3. The XRD spectra of $\mathrm{CoO}_{x} / \mathrm{Al}_{2} \mathrm{O}_{3}$ catalyst (a) $\mathrm{Al}_{2} \mathrm{O}_{3}$, (b) assyn, (c) $T_{\mathrm{C}}=400{ }^{\circ} \mathrm{C}$, (d) $T_{\mathrm{C}}=550{ }^{\circ} \mathrm{C}$, (e) $T_{\mathrm{C}}=700{ }^{\circ} \mathrm{C}$. 


$$
\mathrm{CoO}+\mathrm{H}_{2} \rightarrow \mathrm{Co}+\mathrm{H}_{2} \mathrm{O}
$$

In previous papers $[15,19,20]$ it is shown that the particle size is a determining factor in the reduction process of oxidized cobalt catalysts. The slight shift of reductive peaks from $350,370{ }^{\circ} \mathrm{C}$ to $360,380{ }^{\circ} \mathrm{C}$ (figure $7 \mathrm{c}$, e) indicates that a sintering of cobalt oxide at high temperatures may be possible.

Figure 8 shows the TPR profiles of $\mathrm{CoO}_{x} / \mathrm{Al}_{2} \mathrm{O}_{3}$. The results show more complexity than the $\mathrm{CoO}_{x} / \mathrm{SiO}_{2}$. The profiles consist of low temperature peak around 100 $300{ }^{\circ} \mathrm{C}$ (figure $8 \mathrm{a}, \mathrm{b}$ ), a broad diffuse hydrogen consumption between 500 and $800{ }^{\circ} \mathrm{C}$ (figure $8 \mathrm{a}, \mathrm{b}$ ), a broad consecutive stages peaks around $350-500{ }^{\circ} \mathrm{C}$ and $510-750^{\circ} \mathrm{C}$ (figure $8 \mathrm{c}, \mathrm{d}$ ), a broad peak around 500 $650^{\circ} \mathrm{C}$ (figure 8e) and a high temperature peak above $800{ }^{\circ} \mathrm{C}$ (figure 8e). These reduction regions are assigned to the residue of nitrate ions, trapped of a nitrate ion into the alumina micropore, $\mathrm{Co}_{3} \mathrm{O}_{4}$ crystallite, surface mixed $\mathrm{Co}^{3+}-\mathrm{Al}^{3+}$ oxidic crystalline phase (which is difficult to be reduced), $\mathrm{CoO}$ crystallite and $\mathrm{CoAl}_{2} \mathrm{O}_{4}$ spinel. Since the strong interaction of cobalt nitrate with alumina, the nitrate ion can be trapped by alumina and resist reduction (figure $8 \mathrm{a}, \mathrm{b}$ ). As the calcined temperature arrives $400{ }^{\circ} \mathrm{C}$ (figure $8 \mathrm{c}$ ), the nitrate ion can be

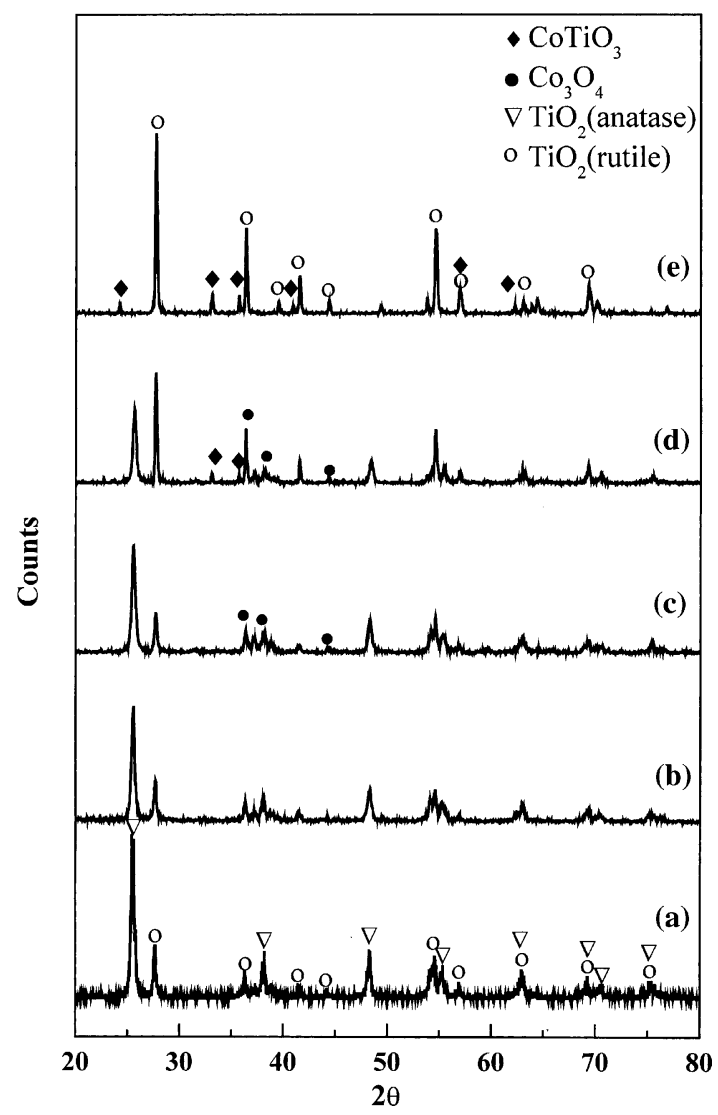

Figure 4. The XRD spectra of $\mathrm{CoO}_{x} / \mathrm{TiO}_{2}$ catalyst (a) $\mathrm{TiO}_{2}$, (b) assyn, (c) $T_{\mathrm{C}}=400{ }^{\circ} \mathrm{C}$, (d) $T_{\mathrm{C}}=550{ }^{\circ} \mathrm{C}$, (e) $T_{\mathrm{C}}=700{ }^{\circ} \mathrm{C}$. removed completely. Also, a distinct reduction of $\mathrm{Co}_{3} \mathrm{O}_{4}$ crystallite is observed (figure 8c, d).

In contrast to $5 \mathrm{Co} / \mathrm{Si} \mathrm{C} 400$ and bulk $\mathrm{Co}_{3} \mathrm{O}_{4}$, the reduction of $\mathrm{Co}_{3} \mathrm{O}_{4}$ on $5 \mathrm{Co} / \mathrm{Al} \mathrm{C} 400$ is actualized in only one-step. Arnoldy and Moulijn [21] also reported one broad peak spectrum for $\mathrm{Co}_{3} \mathrm{O}_{4}$ on $\mathrm{CoO}_{x} / \mathrm{Al}_{2} \mathrm{O}_{3}$ catalyst. They ascribed this peak to the one-step reduction of $\mathrm{Co}_{3} \mathrm{O}_{4}$ to metallic Co. It might be argued that, since the diffusion limitation during a TPR system with smaller particles $\left(\mathrm{CoO}_{x} / \mathrm{Al}_{2} \mathrm{O}_{3}\right)$ is less severe, the stepwise peaks overlapped. While, the peak separation observed for the larger particles (unsupported material) does not diminish, it should enhance. As the calcined temperature arrives to $700{ }^{\circ} \mathrm{C}$ (figure $8 \mathrm{e}$ ), some $\mathrm{Co}_{3} \mathrm{O}_{4}$ decomposed into $\mathrm{CoO}$ and some $\mathrm{Co}^{2+}$ ions diffused into the $\mathrm{Al}_{2} \mathrm{O}_{3}$ lattice to form a surface $\mathrm{CoAl}_{2} \mathrm{O}_{4}$ spinel. The $\mathrm{CoAl}_{2} \mathrm{O}_{4}$ spinel reduces at higher temperature than both $\mathrm{CoO}$ and $\mathrm{Co}_{3} \mathrm{O}_{4}$; obviously due to the existence of $\mathrm{Al}^{3+}$ ions. It is probable that the $\mathrm{Al}^{3+}$ ions polarize the covalent $\mathrm{Co}-\mathrm{O}$ bonds that increase the effective charge of the Co ions [22], i.e., the lattice energy, resulting in an increase of reduction temperature is observed.

Figure 9 shows the TPR profiles of $\mathrm{CoO}_{x} / \mathrm{TiO}_{2}$. The profiles consist of low temperature peak around 100$300{ }^{\circ} \mathrm{C}$ (figure 9a, b), the broad consecutive stages peaks around $310-400$ and $400-600{ }^{\circ} \mathrm{C}$ (figure $9 \mathrm{a}-\mathrm{d}$ ) and a high temperature peak around $550-700{ }^{\circ} \mathrm{C}$ (figure 9e).

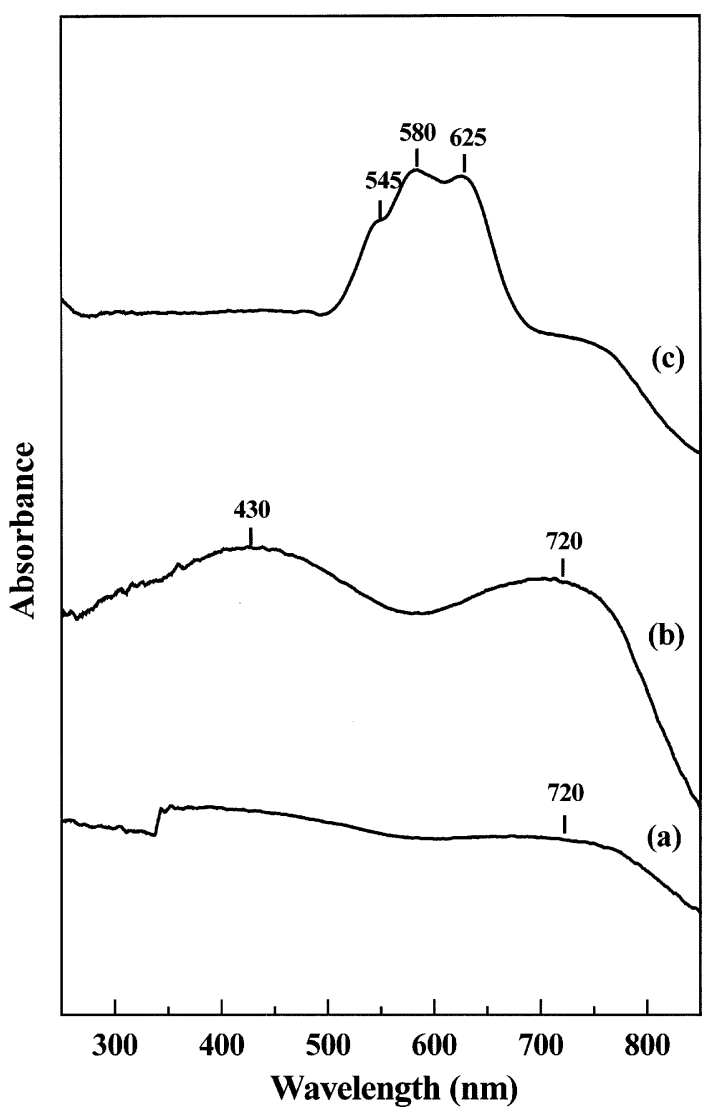

Figure 5. The DRS spectra of $\mathrm{CoO}_{x} / \mathrm{Al}_{2} \mathrm{O}_{3}$ catalyst (a) $T_{\mathrm{C}}=400{ }^{\circ} \mathrm{C}$, (b) $T_{\mathrm{C}}=550{ }^{\circ} \mathrm{C}$, (c) $T_{\mathrm{C}}=700{ }^{\circ} \mathrm{C}$. 
These reduction regions are assigned to the residue of nitrate ion, $\mathrm{Co}_{3} \mathrm{O}_{4}$ crystallite and $\mathrm{CoTiO}_{3}$ spinel. As the DTG and XRD results, the $\mathrm{Co}_{3} \mathrm{O}_{4}$ crystallite that deposited on titania support before calcinations proceeds two stages of reduction (figure 9a). As the calcined temperature arrives to $400{ }^{\circ} \mathrm{C}$ (figure 9c), the nitrate ion can be removed completely. Also, a distinct reduction of $\mathrm{Co}_{3} \mathrm{O}_{4}$ crystallite is observed (figure 9c, d). In contrast to the $\mathrm{CoO}_{x} / \mathrm{SiO}_{2}$ catalyst, the temperature ranges of consecutive reduction stages is broad for the $\mathrm{CoO}_{x} / \mathrm{TiO}_{2}$ catalyst. The signal due to the second stage of reduction for titania supported catalyst is well discernable and shifts to a higher temperature. This indicates that titania has a tendency to stabilize $\mathrm{CoO}$ and resist reduction. As the calcined temperature arrives to $700{ }^{\circ} \mathrm{C}$ (figure 9e), the reduction peak with a maximum at ca. $670{ }^{\circ} \mathrm{C}$ belongs to other species. According to XRD and DRS measurements, from this circumstantial evidence the peak at $670{ }^{\circ} \mathrm{C}$ might be ascribed to the reduction of surface $\mathrm{CoTiO}_{3}$ spinel.

\subsection{Catalytic activities towards the CO oxidation}

The catalytic oxidation of $\mathrm{CO}$ by $\mathrm{O}_{2}$ over supported cobalt catalysts is investigated at temperatures within the

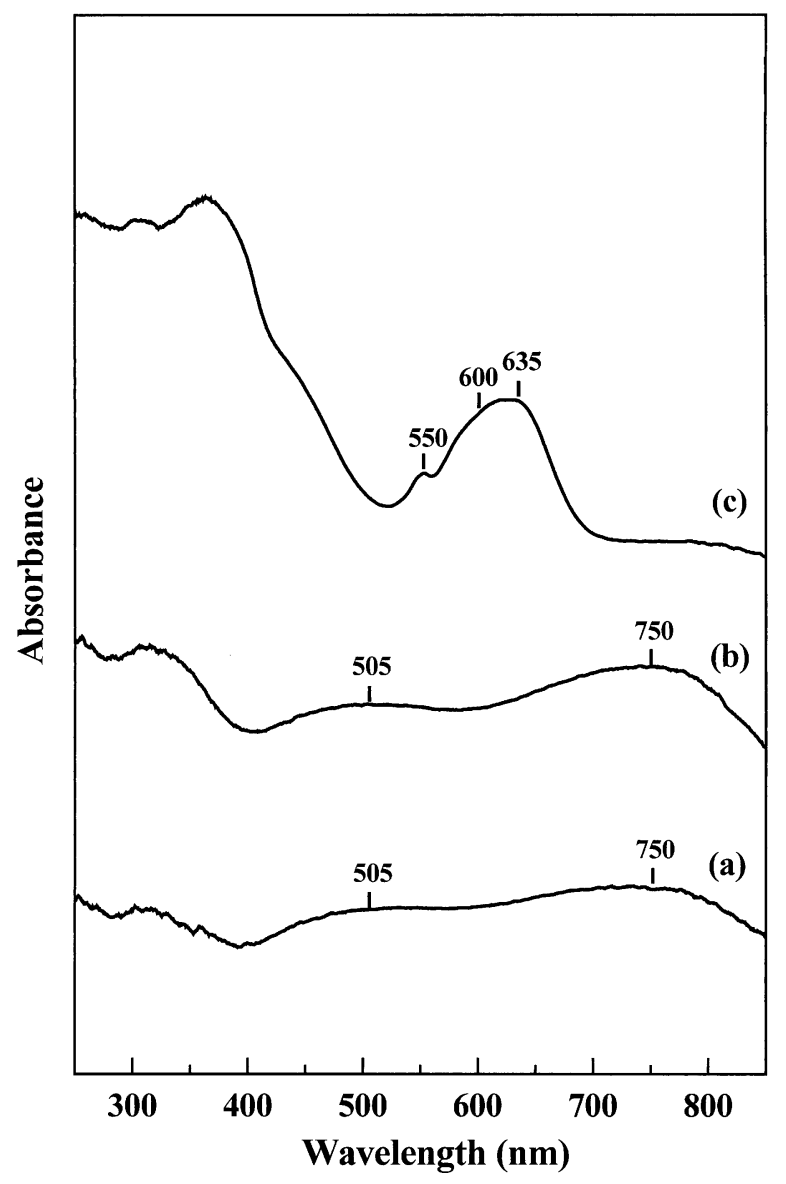

Figure 6. The DRS spectra of $\mathrm{CoO}_{x} / \mathrm{TiO}_{2}$ catalyst (a) $T_{\mathrm{C}}=400{ }^{\circ} \mathrm{C}$, (b) $T_{\mathrm{C}}=550{ }^{\circ} \mathrm{C}$, (c) $T_{\mathrm{C}}=700{ }^{\circ} \mathrm{C}$.
Table 1

Surface area and cobalt species of supported cobalt catalysts at different calcination temperatures

\begin{tabular}{lccl}
\hline Sample & $\begin{array}{c}\text { Calcination } \\
\text { temperature }\left({ }^{\circ} \mathrm{C}\right)\end{array}$ & $\begin{array}{c}\text { Surface area } \\
\left(\mathrm{m}^{2} \mathrm{~g}^{-1}\right)\end{array}$ & Cobalt species \\
\hline $5 \mathrm{Co} / \mathrm{SiC} 400$ & 400 & 186 & $\mathrm{Co}_{3} \mathrm{O}_{4}$ \\
$5 \mathrm{Co} / \mathrm{SiC} 550$ & 550 & 177 & $\mathrm{Co}_{3} \mathrm{O}_{4}$ \\
$5 \mathrm{Co} / \mathrm{SiC} 700$ & 700 & 175 & $\mathrm{Co}_{3} \mathrm{O}_{4}$ \\
$5 \mathrm{Co} / \mathrm{AlC} 400$ & 400 & 102 & $\mathrm{Co}_{3} \mathrm{O}_{4}$ \\
$5 \mathrm{Co} / \mathrm{AlC} 550$ & 550 & 100 & $\mathrm{Co}_{3} \mathrm{O}_{4}$ \\
$5 \mathrm{Co} / \mathrm{AlC} 700$ & 700 & 78 & $\mathrm{CoAl}_{2} \mathrm{O}_{4}$ (blue) \\
$5 \mathrm{Co} / \mathrm{TiC} 400$ & 400 & 43 & $\mathrm{Co}_{3} \mathrm{O}_{4}$ \\
$5 \mathrm{Co} / \mathrm{TiC} 550$ & 550 & 36 & $\mathrm{Co}_{3} \mathrm{O}_{4}$ \\
$5 \mathrm{Co} / \mathrm{TiC} 700$ & 700 & 1.5 & $\mathrm{CoTiO}_{3}$ (green) \\
\hline
\end{tabular}

range of $0-300{ }^{\circ} \mathrm{C}$. The results are presented in figure 10 . The light-off temperature, denoted $T_{50}$, is here defined as the temperature where the conversion of $\mathrm{CO}$ reaches $50 \%$. Conceivably, the observed $T_{50}$ decreased significantly with increasing the calcination temperature, i.e., $5 \mathrm{Co} / \mathrm{Al} \mathrm{C} 400$ $\left(T_{50}=12{ }^{\circ} \mathrm{C}\right) \gg 5 \mathrm{Co} / \mathrm{Al} \mathrm{C} 700\left(T_{50}=232{ }^{\circ} \mathrm{C}\right) ; 5 \mathrm{Co} / \mathrm{Si}$ $\mathrm{C} 400\left(T_{50}=33^{\circ} \mathrm{C}\right) \gg 5 \mathrm{Co} / \mathrm{Si} \mathrm{C} 700\left(T_{50}=202^{\circ} \mathrm{C}\right)$; $5 \mathrm{Co} / \mathrm{Ti} \mathrm{C} 400\left(T_{50}=160{ }^{\circ} \mathrm{C}\right) \gg 5 \mathrm{Co} / \mathrm{Ti} \mathrm{C} 700\left(T_{50}\right.$ is larger than $\left.300{ }^{\circ} \mathrm{C}\right)$.

The best active catalysts are achieved over $5 \mathrm{Co} / \mathrm{Al}$ $\mathrm{C} 400$ and $5 \mathrm{Co} / \mathrm{Si} \mathrm{C} 400$, where $T_{50}$ are reached at temperatures as low as ambient temperature. At lower

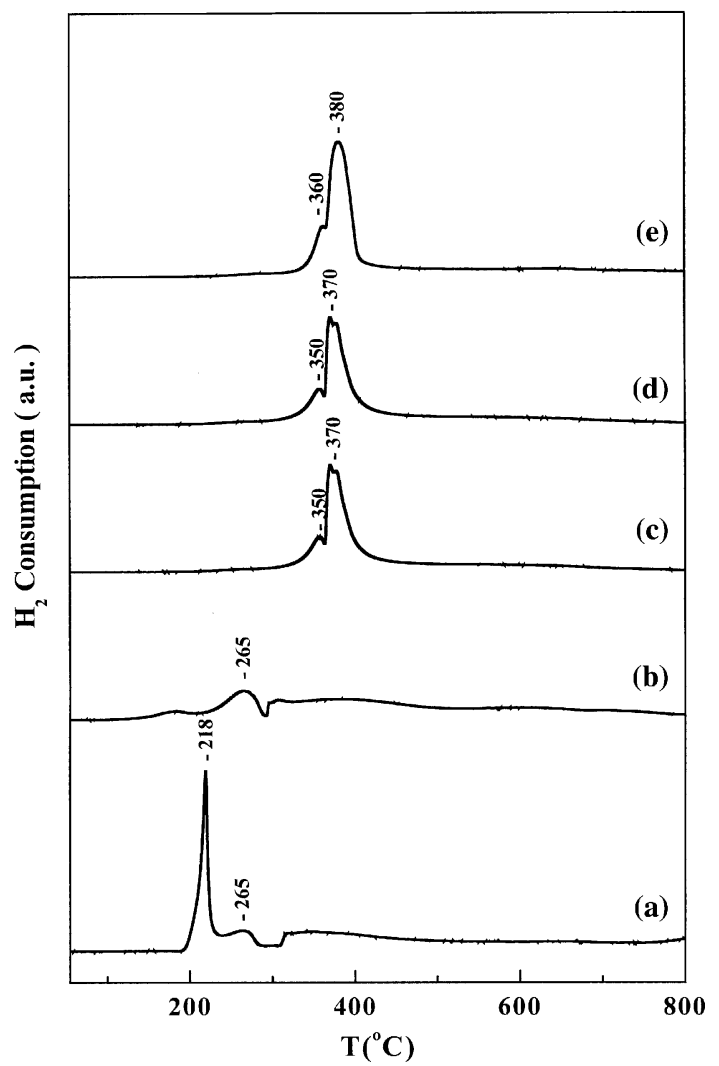

Figure 7. The TPR profiles of $\mathrm{CoO}_{x} / \mathrm{SiO}_{2}$ (a) as-syn, (b) $T_{\mathrm{C}}=200{ }^{\circ} \mathrm{C}$, (c) $T_{\mathrm{C}}=400{ }^{\circ} \mathrm{C}$, (d) $T_{\mathrm{C}}=550{ }^{\circ} \mathrm{C}$, (e) $T_{\mathrm{C}}=700{ }^{\circ} \mathrm{C}$. 


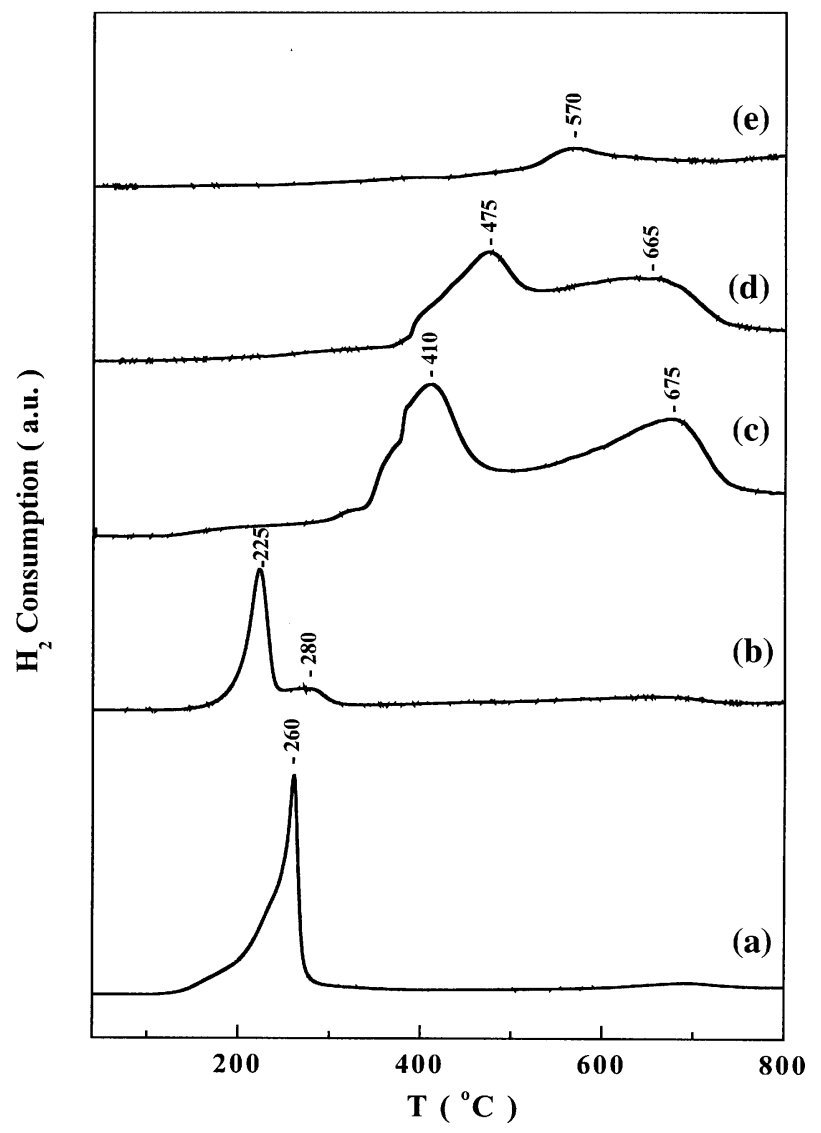

Figure 8. The TPR profiles of $\mathrm{CoO}_{x} / \mathrm{Al}_{2} \mathrm{O}_{3}$ (a) as-syn (b) $T_{\mathrm{C}}=200{ }^{\circ} \mathrm{C}$, (c) $T_{\mathrm{C}}=400{ }^{\circ} \mathrm{C}$, (d) $T_{\mathrm{C}}=550{ }^{\circ} \mathrm{C}$, (e) $T_{\mathrm{C}}=700{ }^{\circ} \mathrm{C}$.

temperatures, the activity increases with the temperature for both catalysts. However, when the temperature above $50^{\circ} \mathrm{C}$, the catalysts have lost their activity and then, the activity recovered as the temperature raises to $100{ }^{\circ} \mathrm{C}$. From TPO experiments, Jansson et al. [23] suggests that the presence of carbonates and surface carbon can deactivate the catalyst. This phenomenon can be eliminated by the regeneration of the deactivated catalyst in $10 \% \mathrm{O}_{2} / \mathrm{Ar}$ atmosphere. In the isotope study, Jansson [6] also confirms that the gas phase $\mathrm{CO}_{2}$ can react with the oxide surface to form a carbonate species. The deactivation found over $5 \mathrm{Co} / \mathrm{Al} \mathrm{C} 400$ and $5 \mathrm{Co} / \mathrm{Si}$ $\mathrm{C} 400$ in the range of $50-100{ }^{\circ} \mathrm{C}$ may therefore be attributed to the coverage of carbonates on catalyst surface. The carbonate may desorb as $\mathrm{CO}_{2}$ again when the temperature raises to $100{ }^{\circ} \mathrm{C}$. Consider the deactivation and the BET surface area of the catalysts (i.e., $102 \mathrm{~m}^{2} \mathrm{~g}^{-1}$ for $5 \mathrm{Co} / \mathrm{Al} \mathrm{C} 400,186 \mathrm{~m}^{2} \mathrm{~g}^{-1}$ for $5 \mathrm{Co} / \mathrm{Si}$ $\mathrm{C} 400$ ), the high surface area of $5 \mathrm{Co} / \mathrm{Si} \mathrm{C} 400$ exhibits lower deactivation. In the same, the lower surface area of $5 \mathrm{Co} / \mathrm{Ti} \mathrm{C} 400\left(43 \mathrm{~m}^{2} \mathrm{~g}^{-1}\right)$ exhibits lower activity than both $5 \mathrm{Co} / \mathrm{Al} \mathrm{C} 400$ and $5 \mathrm{Co} / \mathrm{Si} \mathrm{C400} \mathrm{catalysts.}$

The catalysts via the high temperatures calcination increases the strength of interaction between cobalt oxide and supports that may produce some species, i.e.,

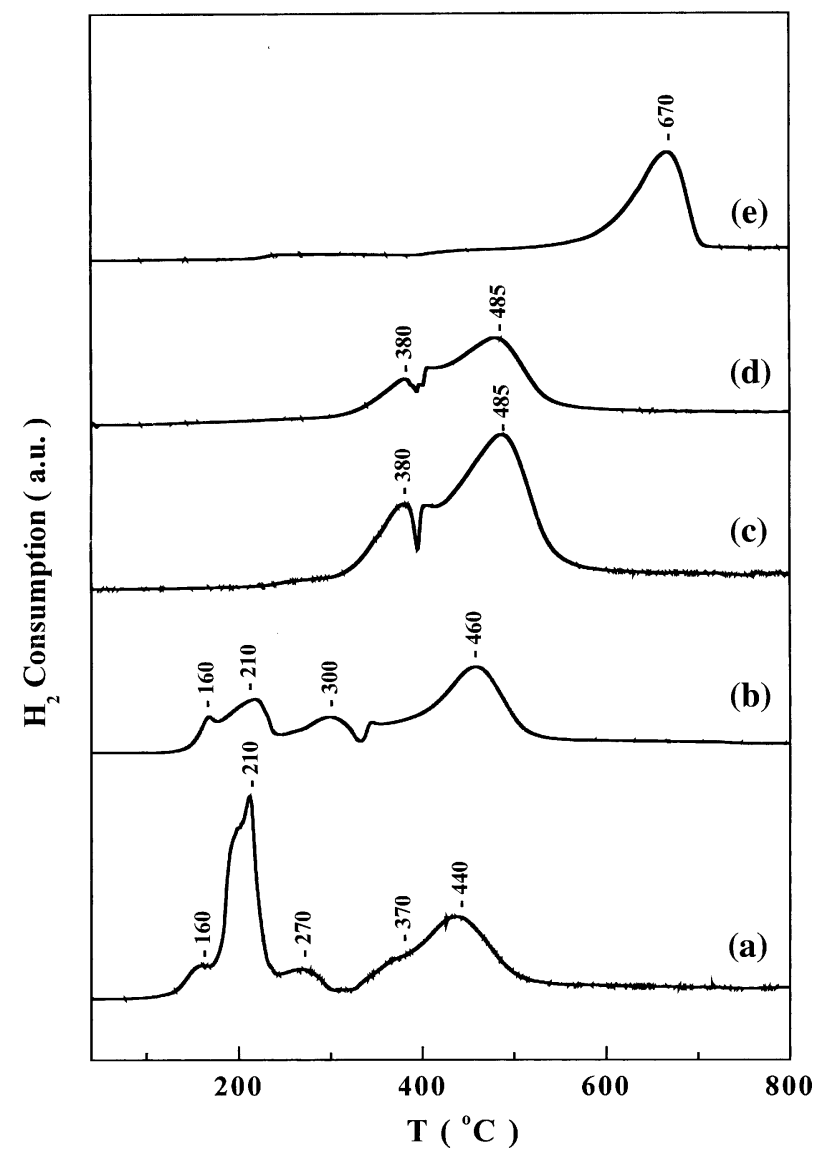

Figure 9. The TPR profiles of $\mathrm{CoO}_{x} / \mathrm{TiO}_{2}$ (a) as-syn, (b) $T_{\mathrm{C}}=200{ }^{\circ} \mathrm{C}$, (c) $T_{\mathrm{C}}=400{ }^{\circ} \mathrm{C}$, (d) $T_{\mathrm{C}}=550{ }^{\circ} \mathrm{C}$, (e) $T_{\mathrm{C}}=700{ }^{\circ} \mathrm{C}$.

cobalt aluminate spinel $\left(\mathrm{CoAl}_{2} \mathrm{O}_{4}\right)$ for $5 \mathrm{Co} / \mathrm{Al} \mathrm{C700} \mathrm{and}$ cobalt titanate spinel $\left(\mathrm{CoTiO}_{3}\right)$ for $5 \mathrm{Co} / \mathrm{Ti} \mathrm{C} 700$. The increase in $T_{50}$ for high temperatures calcination catalysts is clear. As the spinel formed, both the surface area and catalytic activity decreased significantly. Apparently, the variation of $T_{50}$ with the supported cobalt catalysts suggests that the kinds of support and the calcination temperature play an important role on their activity towards $\mathrm{CO}$ oxidation.

\section{Conclusion}

According to what has been shown and discussed above, the following results are found:

1. With a calcined temperature increase, only the $\mathrm{Co}_{3} \mathrm{O}_{4}$ species exists on a $\mathrm{CoO}_{x} / \mathrm{SiO}_{2}$ catalyst surface which sinters slightly with a change in temperature.

2. With a calcined temperature increase, $\mathrm{Co}_{3} \mathrm{O}_{4}$ $\left(T_{\mathrm{C}} \sim 400{ }^{\circ} \mathrm{C}\right)$, surface interaction of $\mathrm{Co}_{3} \mathrm{O}_{4}-\mathrm{Al}_{2} \mathrm{O}_{3}$ $\left(T_{\mathrm{C}} \sim 400{ }^{\circ} \mathrm{C}\right)$, sub-surface interaction of $\mathrm{Co}_{3} \mathrm{O}_{4}$ $\mathrm{Al}_{2} \mathrm{O}_{3}\left(T_{\mathrm{C}} \sim 550{ }^{\circ} \mathrm{C}\right)$ and $\mathrm{CoAl}_{2} \mathrm{O}_{4}\left(T_{\mathrm{C}} \sim 700{ }^{\circ} \mathrm{C}\right)$ become the dominant species on a $\mathrm{CoO}_{x} / \mathrm{Al}_{2} \mathrm{O}_{3}$ catalyst.

3. With a calcined temperature increase, $\mathrm{Co}_{3} \mathrm{O}_{4}$ $\left(T_{\mathrm{C}} \leq 400{ }^{\circ} \mathrm{C}\right)$, sub-surface interactions of $\mathrm{Co}_{3} \mathrm{O}_{4-}$ 


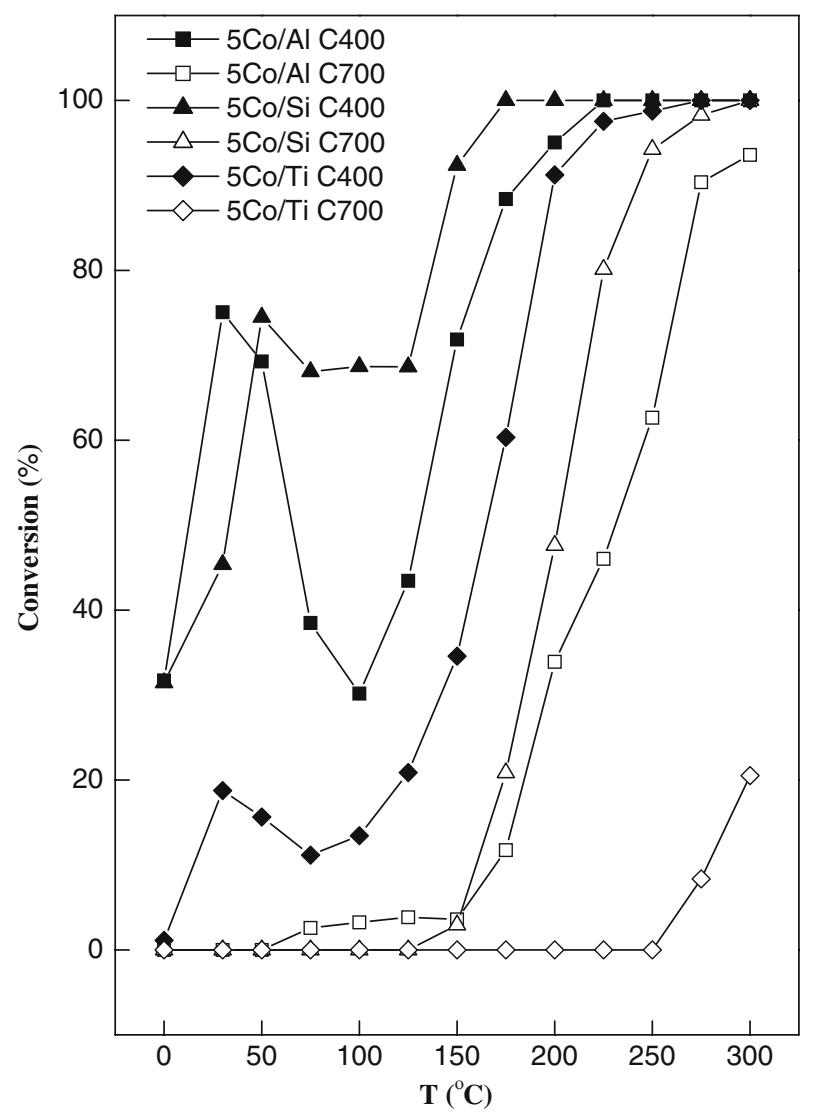

Figure 10. Conversion profiles for $\mathrm{CO}$ oxidation over supported cobalt catalysts.

$\mathrm{Al}_{2} \mathrm{O}_{3}\left(T_{\mathrm{C}} \sim 550{ }^{\circ} \mathrm{C}\right)$ and $\mathrm{CoTiO}_{3}\left(T_{\mathrm{C}} \sim 700{ }^{\circ} \mathrm{C}\right)$ become the dominant species on a $\mathrm{CoO}_{x} / \mathrm{TiO}_{2}$ catalyst.

4. The catalytic activities towards the $\mathrm{CO}$ oxidation are decreased significantly with the calcination temperature and depends on the kinds of support.

\section{Acknowledgment}

We are pleased to acknowledge the financial support for this study by the National Science Council of the
Republic of China under contract number NSC 922113-M-014-001.

\section{References}

[1] D.A.H. Cunningham, T. Kobayashi, N. Kamijo and M. Haruta, Catal. Lett. 25 (1994) 257.

[2] Y.M. Kang and B.Z. Wan, Catal. Today 26 (1995) 59.

[3] Y.J. Mergler, A. van Aalst, J. van Delft and B.E. Nieuwenhuys, Appl. Catal. B 10 (1996) 245.

[4] Y.J. Mergler, J. Hoebink and B.E. Nieuwenhuys, J. Catal. 167 (1977) 305.

[5] P. Thormählen, M. Skoglundh, E. Fridell and B. Andersson, J. Catal. 188 (1999) 300.

[6] J. Jansson, J. Catal. 194 (2000) 55.

[7] M. Kang, M.W. Song and C.H. Lee, Appl. Catal. A 251 (2003) 143.

[8] H.K. Lin, H.C. Chiu, H.C. Tsai, S.H. Chien and C.B. Wang, Catal. Lett. 88 (2003) 169.

[9] J.C. Duchet, M.J. Tilliette and D. Conrnet, Catal. Today 10 (1991) 507.

[10] M. Lojacono, A. Cimino and G.C.A. Schuit, Gazz. Chim. Ital. 103 (1973) 1281.

[11] F.J. Gillambias, A.L. Agudo and V. Rives-Arnau, J. Mater. Sci. 17 (1982) 936.

[12] G.N. Asmolov and O.V. Krylov, Kinet. Katal. 12 (1971) 463.

[13] E.I. El'Bert and B.G. Tryasunov, Kine Katal. 16 (1975) 552.

[14] A. Lapidus, A. Krylova, V. Kazanskii, V. borovkov and A. Zaitsev, Appl. Catal. 73 (1991) 65.

[15] T. Paryjczak, J. Rynkowski and S. Karski, J. Chromat. 188 (1980) 254.

[16] P. Brown, M.E. Cooper and D.A. Whan, Appl. Catal. A 3 (1982) 177.

[17] B.A. Sexton, A.E. Hughes and T.W. Turney, J. Catal. 97 (1986) 390.

[18] E.V. Steen, G.S. Sewell, R.A. Makhothe, C. Micklethwaite, H. Manstein, M. de Lange and C.T. O'Connor, J. Catal. 162 (1996) 220.

[19] R.C. Reuel and C.H. Bartholomew, J. Catal. 85 (1984) 63.

[20] Y. Okamoto, K. Nagata, T. Adachi, K. Imanaka, K. Inamura and T. Takyu, J. Phys. Chem. 95 (1991) 310.

[21] P. Arnoldy and J.A. Moulijn, J. Catal. 93 (1985) 38.

[22] H.H. Kung, J. Catal. 73 (1982) 387.

[23] J. Jansson, A.E.C. Palmqvist, E. Fridell, M. Skoglundh, L. Österlund, P. Thormählen and V. Langer, J. Catal. 211 (2002) 387. 